\title{
The effect of gastric dilatation in rats submitted to gasified water ingestion under the hepatic metabolic function ${ }^{1}$
}

\author{
Efeito da dilatação gástrica em ratos submetidos à ingestão de água gaseificada sobre a função \\ metabólica hepática
}

\author{
José Roberto Ferreira Santiago', Shoiti KobayasiI ${ }^{\text {II }}$ \\ ${ }^{\text {I }}$ Post graduate in Surgery [doctorate], Medical School of Botucatu, UNESP, Sao Paulo, Brazil. \\ ${ }^{\text {II }}$ Full Professor, Division of Surgical Gastroenterology, Department of Surgery and Orthopedics, Medical School of Botucatu, UNESP, Sao Paulo, Brazil.
}

\begin{abstract}
Introduction: The amounts of people that are overweight have been increasing within the population in significant ways during the last decades. In this view, gasified beverages have become an important environmental concern in relation to the eating habits of people, especially who lives in the USA, Mexico, and Brazil. In this order, these three countries constitute the major beverages producers and consumers of the whole world. Purpose: To investigate the effects of gastric dilatation in rats submitted to gasified water ingestion, uniform vehicle for all soft drinks, under metabolic patterns of the hepatic function. Methods: Two groups of 15 rats were formed and observed during two weeks. The rats of the group I, were fed with $200 \mathrm{~g} / \mathrm{day}$ of rat food ad libitum and $100 \mathrm{ml}$ of non-gasified water during three daily periods. The rats composing the group II, were fed with $200 \mathrm{~g} /$ day of rat food ad libitum and $100 \mathrm{ml}$ of gasified water within 3 daily periods. The media (x) and standard deviation (s) were calculated through the paired t-test for each group in order to compare the effects of the different types of water and its effect in each one of them. Results: The results indicated that the animals which were submitted to the treatment with gasified water (G-II), presented an increase of glutamic-pyruvic transaminase (GPT) and alkaline phosphatase (ALP) $(p<0,01)$, tendency to increase the glutamic-oxaloacetic transaminase (GOT) $(0,10>p>0,05)$ and increase of the gastric area with macroscopic morphologic alterations, such as the loss of the characteristic linear depressions on the surface of the mucous membrane. Conclusion: The gasified water favored the expansion of the gastric area and contributed to the extinction of the linear depressions of the mucous organ, which caused metabolic alterations of the hepatic function.
\end{abstract}

Key words: Metabolism. Liver. Transaminases. Carbonated Beverages. Coolings. Stomach. Rats.

\section{RESUMO}

Introdução: O excesso de peso na população aumentou de forma significante nas últimas décadas e as bebidas gasosas tornaram-se um fator ambiental importante no comportamento alimentar das pessoas, sendo os EUA, México e Brasil, nesta ordem, os três maiores paises produtores e consumidores de refrigerantes. Objetivo: Investigar os efeitos da dilatação gástrica em ratos submetidos a ingestão de água gaseificada, veículo uniforme para todos os refrigerantes, sobre parâmetros metabólicos da função hepática. Métodos: Foram constituídos dois grupos de 15 ratos acompanhados por 15 semanas. Ao Grupo-I, foram oferecidos $200 \mathrm{~g} /$ dia de ração ad libitum e 100 $\mathrm{ml}$ de água não gaseificada em 3 períodos diários, ao Grupo-II, foram oferecidos $200 \mathrm{~g} /$ dia de ração ad libitum e $100 \mathrm{ml}$ de água gaseificada em 3 períodos diários; em cada grupo,foram calculados a média (x) e o desvio padrão (s); para todos os atributos estudados foi utilizado o método estatístico de teste t pareado, comparando-se GI com GII, testando-se o efeito dos tipos de água. Resultados: Os resultados identificaram que os animais que foram submetidos ao tratamento com água gaseificada (Grupo-II), apresentaram um aumento de transaminase glutâmica pirúvica (TGP) e fosfatase alcalina $p<0,01$ ), tendência de aumento da transaminase glutâmica oxalacética (TGO) $(0,10>p>0,05)$ e aumento da área gástrica com alterações morfológicas macroscópicas como o desaparecimento do pregueamento mucoso característico. Conclusão: A água gaseificada favoreceu o aumento da área gástrica com conseqüente desaparecimento macroscópico do pregueamento mucoso do órgão, que ocasionou alterações metabólicas da função hepática.

Descritores: Metabolismo. Fígado. Transaminases. Bebidas Gasosas. Refrigerantes. Estômago. Ratos.

${ }^{1}$ Research performed at Division of Surgical Gastroenterology, Department of Surgery and Orthopedics, Medical School of Botucatu, State University (UNESP), Sao Paulo, Brazil.

\section{Introduction}

The gasified beverages are inserted among all social classes, constituting than an important environmental factor in the population's eating habits nowadays. This was demonstrated in a research realized in Mexico City, where the authors concluded that $82.3 \%$ of the population ingested daily amounts of soft drinks, which results in a average of 0.6 liter/day and 3.5 liter/week, independent of the educational level ${ }^{1}$. 
By analyzing the effects of the soft drinks sweetened with aspartame compared to the ones sweetened with sacarose, researchers observed that the ingestion of these substances significantly increase the entrance of macronutrients in the diet, independent of the manner that they were sweetened. They suggested therefore that gasified beverages sweetened with aspartame do not diminish the ingestion of other foods; moreover it allows larger ingestion of nutrients in the subsequent days ${ }^{2}$.

The risks and damages related to the ingestion of soft drinks are many. Some examples are dental disorders, alterations in the mineral metabolism, peptic acid disease, risk factors for cardiovascular diseases, and effects in the central nervous system due to the caffeine ingestion, among others. It is well know that the excessive consume of soft drinks can represent a problem to the public health ${ }^{3}$.

There was a significant increase in the ingestion of gasified beverages from the year of 1947 until 1997, as a result of an intense advertisement promoting its easy access. The gasified beverages provide large amounts of sugar that results into an epidemic weight gain since there is a replacement of milk, which contributes to a large number of osteoporosis, dental problems and nefrolitiasis, in addition to the fact that other substances can lead to cardio diseases, insomnia, behavioral problems, allergic reactions, as well as increase the risk for cancer ${ }^{4}$.

With the production of 11.5 billions/litters of soft drinks in the year of 2002, Brazil occupied the $3^{\text {rd }}$ place in the world's annual equity ratio of R $\$ 12$ billions, being overcome only by the USA, and Mexico. The national consume increased five times from the year of 1992 to 2002, ranking in 69 litters per habitant/year in the later, at this time overcome by the USA, México and Germany, and becoming the fourth country to consume soft drinks in the whole world ${ }^{5}$.

In addition, clinical observation of obese patients in intake treatment, indicates that the people that indiscriminately make use of gasified beverage present an inappropriate response to the dietetic treatment. At the time that these patients drop the treatment, they rapidly gain the previous weight, especially when compared to the ones that did not drink gasified beverages.

This clinical observation leaded to an experimental research. Based on the knowledge that soft drinks have the carbonic gas as a common factor, a study was planed to investigate the effects of gasified water in 4 groups of 12 rats. These animals were observed during 36 days with the purpose of analyzing the hydric ingestion and food intake, weight gain, gastric area dilatation, glycemia, hematocrit and hemoglobin. The results indicated that the animals that were submitted to the treatment with gasified water presented a higher volume of hydric ingestion and significant expansion of the gastric area. Moreover, the extended eating intake caused a significant weight gain in the animals treated with the same water. Nevertheless, the glycemia hematocrit and hemoglobin data did not demonstrated significant alterations in any group ${ }^{6}$.

The gastric areas were analyzed through radiographic exam and revealed significant enlargement in the animals that made use of gasified water after five weeks of experimentation. The conclusion pointed that the $\mathrm{CO}_{2}$ would be one of the subtracts responsible for the morphologic alteration of the stomach ${ }^{6}$. However, the weight control begun to present alterations since the end of the fourth week of experimental investigation, leading thus to the conclusion that the gasified water increased both, the volume of hydric ingestion and dry food intake. Therefore, the animals' weight increased since the fifth week of experimentation as well ${ }^{6}$.
We also thought that it would be important to investigate whether the extended use of gasified water contributed to the more substantial expansion of the gastric area in successive weeks of experimentation, and consequently, leading to alterations in the hepatic metabolic function. In order to achieve this, we focused on literature reviews that investigate the effects of the gasified beverages in different metabolic functions of the organism such as the biochemical and serical doses of pyruvic transaminase, oxaloacetic, and alkaline phosphatase. The literature review gathered in the last years allowed to comprehend certain aspects of the genesis of gastric dilatation. However, it did not clarify if the gasified content of the soft drinks, throughout their interferences in the stomach morphology, affects the hepatic metabolism ${ }^{1-4}$.

To answer this question, the present study had as its main purpose to study the effects of gasified water in rats, during a period of fifteen weeks of experimentation having as its basis the gastric macroscopic morphology, laboratorial blood doses of alkaline phosphatase, glutamic transaminase, and oxaloacetics.

\section{Methods}

Sixty-months-old Wistar rats, albinus norvegicus, average weight $260 \mathrm{~g}$, maintained for a period of 30 days in acclimatation and daily evaluation, were utilized in order to observe whether they would present any clinical signs that could cause any impairment for the treatment. Ended the acclimatation period, 30 animals were randomly selected and separated into two equal groups to initiate the experiment. The groups were constituted by the following manner: In Group I (GI), 15 animals were submitted to a diet free of rat food* and ingestion of industrial water with no gas** during a period of 24 hours, which process was repeated during 100 days. In Group II (GII) - 15 animals were submitted to a diet free of rat food* and industrialized gasified water ingestion during 24 hours, and this process was repeated for 100 days. The water of all 30 rats was changed during three daily periods, $7 \mathrm{am}, 1 \mathrm{pm}$, and $7 \mathrm{pm}$ respectively, and the food was changed once a day, during 100 sequential days. The experimental design is demonstrated in Figure 1.

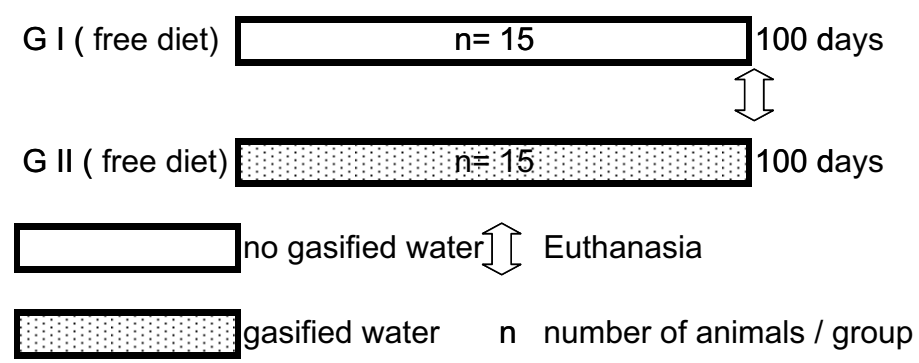

FIGURE 1 - Experimental design

*Dry food of the Labina (Purina) branch adapted to rats and mice. **Gasified and no-gasified water from the same branch and same production chain.

The animals of the experimental groups I and II were evaluated in chronologically corresponded moments. All methodological items were submitted to the analysis of the Experimental Research Ethical Committee of the UNESP(Botucatu-SP, form no. 352/2003) and had its steps approved during a previous meeting of the Ethical Committee and Animal Research (ECAR) 
on October15th, 2003. After the realization of euthanasia performed through acute bleeding by cardio pulse under anesthesia (xilazina and ketamine $3 \mathrm{mg} / \mathrm{kg} / \mathrm{IM}$ ), and the blood sent to laboratorial analysis of transminases and alkaline phosphatase, it was realized a laparotomy through an incision of the stomach until its complete exposure. Following, the distal zone of the esophagus and the proximal duodenum was dissected with the scalpel and the organ was extracted from the abdominal cavity (Figure 2) so that it could be conditioned in glasses recipients containing neutral formalin at $10 \%$ in phosphate tampon. The macroscopic morphology of the organ was studied, so that a comparison of its size in a closed situation could be performed in order to realize the stomach's insure through its small curvature, and comparatively observe the differences in the internal morphologic formation.

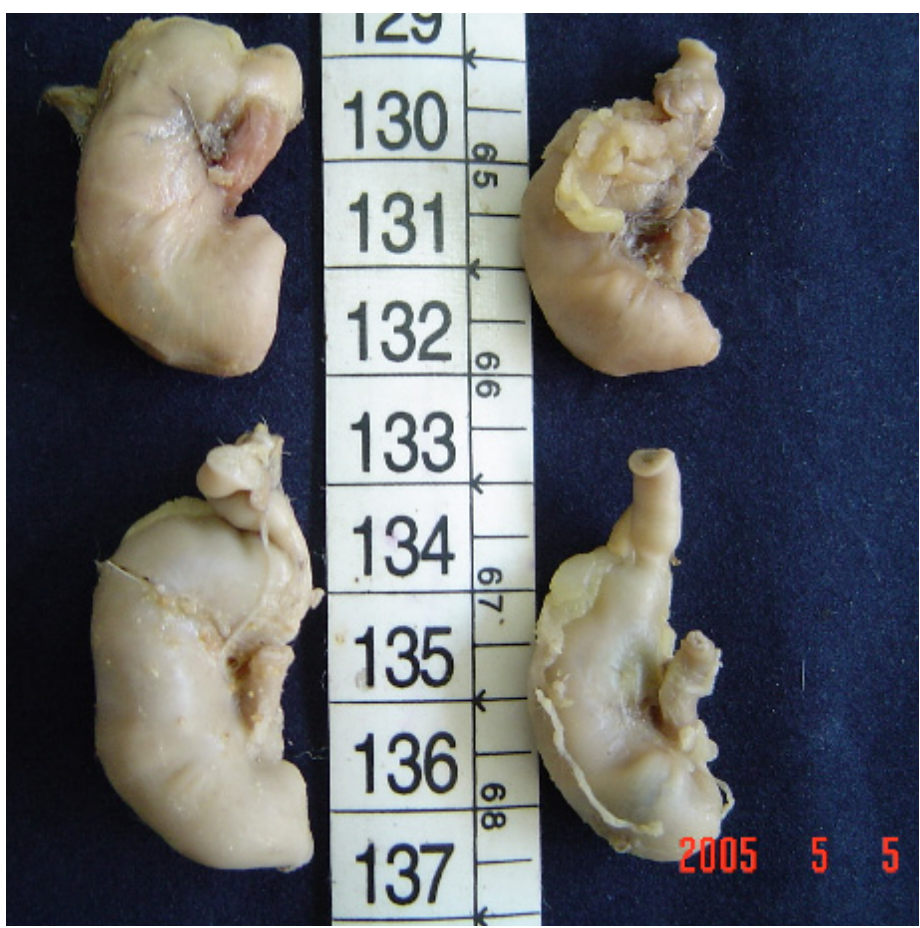

FIGURE 2 - Stomachs extracted from the abdominal cavity revealing the external macroscopic anatomy of the rats. Examples of group I on the right and group II on the left can be observed

\section{Statistical analysis}

In this experiment two kinds of water, with or without gas, were evaluated in two distinct groups of rats with the same age, randomly chosen within a group of 30 animals, 15 for each group. In each group were calculated the media (x) and standard deviation (s) for all quantitative analysis. Tables were drown with the medium values of the groups in order to provide the analysis of the results and apply the statistical model of paired t-test, so that a comparison between GI and GII as well as the analysis of the water types could be done. In order to answer the hypothesis, which is the water effects in the experimental groups, the $t$ and $p$ statistical methods were also calculated, and considered significant $(\mathrm{p}<0,05$, being $p$ the probability of erroneously conclude by significance $)^{7}$. Finally, for contrasts among medium pairs, the minimum significant difference (MSD) $\alpha=0,05$ was calculated through the TUKEY method, when $0,05<\mathrm{p}<0,10$ demonstrated tendency to significance.

\section{Results}

The external macroscopic gastric morphology of the studied animals was found different in animals that used gasified water, in relation to the ones that did not use it. The results demonstrated the following main characteristics: global expansion of the external volume of the organ (GII) and increase predominantly acute of the gastric bottom (GII). These differences are illustrated in Figure 3.

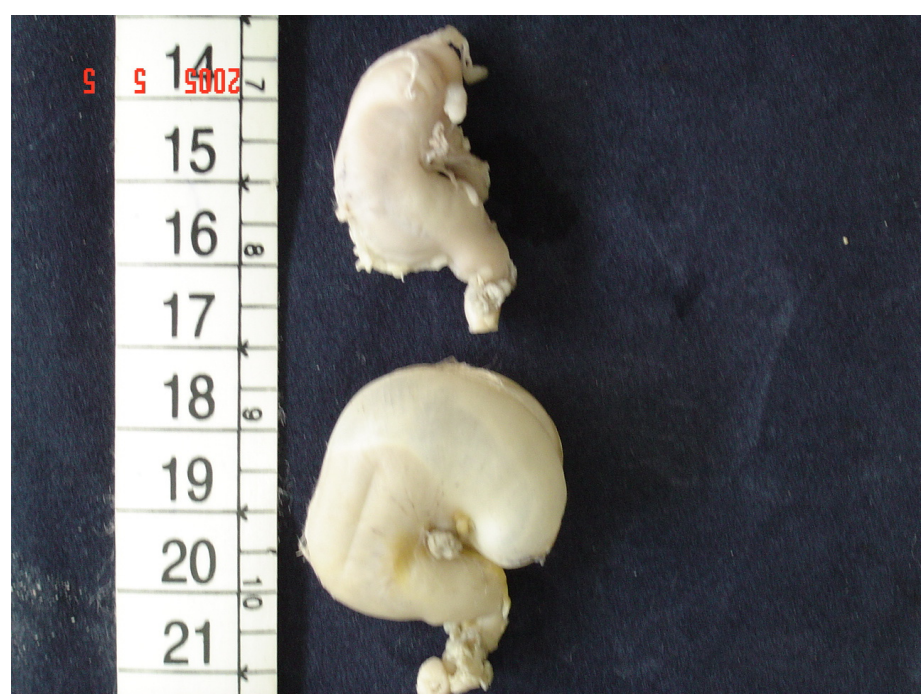

FIGURE 3 - The figure shows the examples of GI located at the top of the picture and G II at the bottom of the picture, revealing external macroscopic differences of the rats' stomachs

The internal macroscopic observation of the stomach, realized through its exposition with the incision in the small curvature of the duodenum until the posterior part of the gastric bottom, reveals accentuated difference, occurring extinction of the linear depressions of the mucous organ in the animals that made use of gasified water when compared to the animals that utilized no gas water, as it is illustrated in Figure 4.

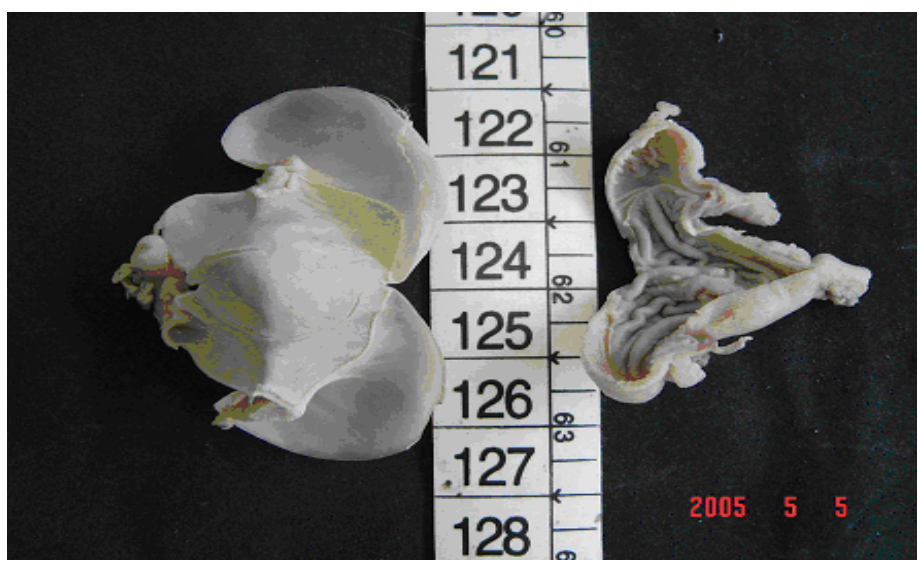

FIGURE 4 - Examples of the group G I at right and group G II at left, revealing the extinction of the linear depressions of the gastric mucous organ of the animal that ingested gasified water 
The results of the doses of glutamic oxaloacetics transaminase blood did not show significant difference among the investigated animal groups; however, there was a tendency of increasing in G II, as it is demonstrated in Table 1.

TABLE 1 - Medium values of glutamic oxaloacetics transaminase (GO-T) in international units through cubic millimeters of blood $(\mathrm{U} / \mathrm{mm} 3)$ and respective standard deviations, in the experimental groups

\begin{tabular}{l|l}
\hline ANIMAL GROUPS $^{\mathrm{a}}$ & GO-T $\left(\mathbf{U} / \mathbf{M M}^{3}\right)$ \\
\hline G I - (free diet and no gas water) & $197.67( \pm 197,82)^{\mathrm{b}}$ \\
\hline G II - (free diet and gas water) & $286,07( \pm 197,82)^{\mathrm{c}}$ \\
\hline${ }^{\mathrm{a}} \mathrm{n}=15$ for all groups & ${ }^{\mathrm{b}<\mathrm{c}} t=-2,11 ; 0,10>p>0,05:$ GI $<\mathrm{GII}$
\end{tabular}

The blood levels of glutamic-pyruvic transaminase (GP-T) revealed significant increase in the group treated with gasified water, as it is demonstrated in Table 2.

TABLE 2 - Medium values of glutamic-pyruvic transaminase (GP-T) in international unities by blood cubic millimeters $(\mathrm{U} / \mathrm{mm} 3)$ and respective standard deviations, in the experimental groups

\begin{tabular}{l|l}
\hline ANIMAL GROUPS $^{\mathrm{a}}$ & GP-T $\left(\mathbf{U} / \mathbf{M M}^{3}\right)$ \\
\hline $\mathrm{G}$ I $-($ free diet and no gas water) & $79,40( \pm 21,57)^{\mathrm{b}}$ \\
\hline $\mathrm{G}$ II $-($ free diet and gas water) & $144,07( \pm 27,14)^{\mathrm{c}}$ \\
\hline${ }^{\mathrm{a}} \mathrm{n}=15$ for all groups & ${ }^{\mathrm{b}<\mathrm{c}} t=-6,67 ; p<0,001: \mathrm{GI}<\mathrm{GII}$
\end{tabular}

The variations of the levels of seric alkaline phosphatase (ALP), showed a significant increase in the group treated with gasified water, as it is demonstrated in Table 3.

TABLE 3 - Medium values of the levels of alkaline phosphatase, seric in international unities by cubic millimeters $(\mathrm{U} / \mathrm{mm} 3)$ and respective standard deviation, in the experimental groups

\begin{tabular}{l|c}
\hline ANIMAL GROUPS $^{\mathrm{a}}$ & ALP $\left(\mathbf{U} / \mathbf{M M}^{3}\right)$ \\
\hline $\mathrm{G} \mathrm{I}-($ free diet and no gas water) & $84.33( \pm 197,82)^{\mathrm{b}}$ \\
\hline $\mathrm{G}$ II $-($ free diet and gas water) & $160,47( \pm 197,82)^{\mathrm{c}}$ \\
\hline${ }^{\mathrm{a}} \mathrm{n}=15$ for all groups. & ${ }^{\mathrm{b}<\mathrm{c}} t=-3,84 ; p<0,001: \mathrm{GI}<\mathrm{GII}$
\end{tabular}

\section{Discussion}

The literature presents many factors as the cause for gastric dilatation, such as diet composition, postprandial exercise, huge food quantity ingestion, bacteria action in carbohydrates, chloridric acid effect in solutions containing bicarbonate, aerophagia, among others, and for all of them there is a common factor which is the gas accumulation with consequent dilatation ${ }^{8-13}$.
The gastric dilatation effect must consider the factors that normally impair the gastroesophageal reflux, as the oblique angule of the gastroesophagic junction and its inferior muscles, in addition to intra-abnominal esophagus, pillars diaphragmatic and the fundic pressure. Among other factors those are efficient for making possible the normal eructation of the ingested gas and impair the pathological reflux ${ }^{14}$.

The rats' stomachs show a macroscopic division in two parts, a cardiac portion that is translucent and other pyloric that is more opaque. Histologically, these areas also present distinct differences that begins with stratified variations and goes to the predominantly glandular epithelium. The esophagus thus, penetrates into these two areas serving as the separating boundary, which is macroscopically denominated as bottom and gastric cavity ${ }^{15}$.

The situation of a very distended and filled with liquid and food stomach, as it is perfectly possible after a rich meal, can present the organ twist in a more easy way than the empty stomach, since this alteration can turn flabby the gastric ligaments ${ }^{16}$.

The most important factor that makes possible the gastric volvulus, is the flabbiness of the ligaments, which normally sustains the stomach in the abdominal cavity. Among these hamstrings are the hepatic gastric, gastrosplenic, gastrocolic, gastrophrenic, and the fix retroperitoneal portion of the duodenum that maintains the gastric position in caudal direction ${ }^{9-16}$.

When the integrity of the ligament support system of the stomach is compromised in its superior portion, the movement of the larger curvature in the cranium direction will result into an organoaxial gastric volvulus, "stomach turned down", while the flabbiness of the fix retroperitoneal portion of the duodenum will provoke mesenteroaxial gastric volvulus ${ }^{10,11,17}$.

In laparotomized animals that ingested gasified water, gastric dilatation of fundic predominance observed, which consequently can provoke tension and flabbiness of the cranium gastric ligaments. This situation, when associated to a stomach filled with liquid, such as in the animals using gasified water, makes possible to cause a more easily torsion than the stomach of animals that did not used gasified water and have its anatomy preserved.

In addition to the predisposition to the gastric volvulus development, the progressive gastric dilatation can cause esterase and venous congestion of the vascularization adjacent to the very stomach. Its compressive action on the esplenic vessels, caudal caval vein and portal system, as the derivation system through the azygos vein is not sufficient to compensate the reduction of the venous return. This congestion thus will provoke esplenic vascular complications, renal, posterior and hepatic muscles, provoking the portal hypertension $^{11-17}$.

It is known that the gas accumulation in the stomach of dogs in progressive manners in experimental conditions elevates the pressure until $80 \mathrm{mmHg}$ and reduces the oxygen tension in $92 \%$ having its effects causing isquemic lesions of the organ mucous, especially in the large curvature of the bottom and gastric body ${ }^{17}$. 
The laboratorial results of the present investigation revealed a significant raise of the pyruvic transaminase, alkaline phosphatase and tendency of increasing the oxaloacetics transaminase, indicating hepatic disfunction. In this study, these enzyme elevations of the hepatic function suggest that the compressive effects of the stomach on the adjacent vascularization can have provoked a congestion that includes the hepatic circulation and consequently causes this dysfunction.

The hepatic lesion is common in spontaneous and experimental cases of gastric dilatation, reflecting in a smooth to severe elevation of the serical concentrations of transaminases and alkaline phosphatase. The extrinsic vascular congestion and intrinsic gastric ischemia, due to the stomach dilatation, can reduce the system's hepatic endothelial reticulum capacity. This scenery, by itself would narrow the bacteria and eliminates endotoxines that can be absorbed by the mucous gastrointestinal ischemia ${ }^{17}$.

A recent study demonstrated that the plasmatic levels of endotoxines were higher in dogs with gastric dilatation due to the bigger intestinal absorption and hepatic intestinal elimination ${ }^{10,18}$.

\section{Conclusion}

In the rat and the conditions in which the present investigation was realized, it can be concluded that the use of gasified water provoked gastric dilatation with consequent elevation of the levels of glutamic-pyruvic transaminase (GPT) and phosphatase alkaline (ALP), as well as provoked tendency to enhance the levels of glutamic-oxaloacetics transaminase (GO-T).

\section{References}

1.Maupome-Carvantes G, Sanchez-Reyes V, Laguna-Ortega S, AndradeDelgado LC, Bonilla-Calderon JD. Patrón de consumo de refrescos en una población mexicana. Salud Publica Mex. 1995;37(4):323-8.

2.Lavin JH, French SJ, Read NW. The effect of sucrose and aspartamesweetened drinks on energy intake, hunger and food choise of female, moderately restrained caters. Int J Relat Metab Disord. 1997;21(1):37-42. 3.Amato D, Maravilla A, Garcia-Contreras F, Paniagua R. Los refrescos y la salud. Rev Invest Clin. 1997;49(5):387-95.
4.Jacobson MF. Liquid candy: how soft drinks are harming americans'health. Internet: (Accessed April 2001). http://www.cspinet.org/ sodapop/liquid_candy/htm

5.Salata CC. Tecnologia de refrigerantes [Mestrado]. Botucatu: Faculdade de Ciências Agronômicas, Universidade Estadual Paulista; 2002.

6.Santiago JRF, Kobayasi S, Granjeiro JM. Increase of gastric area and weight in rats submitted to the ingestion of gasified water. Acta Cir Bras. [serial on the Internet] 2004;19(3):220-37. Available from URL: http:// www.scielo.br/acb

7.Curi PR. Metodologia e análise da pesquisa em ciências biológicas. 2ed. Botucatu: Tipomic; 1978.

8.Dennler R, Koch D, Hassig M, Howard J, Montavon PM. Climatic conditions as a risk factor in canine gastric dilatation-volvulus. Vet $\mathrm{J}$. 2005;169(1):97-101.

9.Mathevon T, Rougier C, Ducher E, Pic D, Garcier JM, Schmidt J. Acute abdominal dilatation, a serious complication in the case of anorexia nervosa. Presse Med. 2004;33(9 Pt 1):601-3.

10.Raghavan M, Glickman N, McCabe G, Lantz G, Glickman LT. Dietrelated risk factors for gastric dilatation-volvulus in dogs of high-risk breeds. J Am Anim Hosp Assoc. 2004;40(3):192-203.

11.Monnet E. Gastric dilatation-volvulus syndrome in dogs. Vet Clin North Am Small Anim Pract. 2003;33(5):987-1005.

12.De Caprio C, Pasanisi F, Contaldo F. Gastrointestinal complications in a patient with eating disorders. Eat Weight Disord. 2000;5(4):228-30.

13.Todd SR, Marshall GT, Tyroch AH. Acute gastric dilatation revisited. Am Surg. 2000;66(8):709-10.

14.Hirsch DP, Mathus-Vliegen EM, Dagli U, Tytgat GN, Boeckxstaens GE. Effect of prolonged gastric distention on lower esophageal sphincter function and gastroesophageal reflux. Am J Gastroenterol. 2003;98(8):1696-704.

15.Greene EC. Gross anatomy. In: Farris JE, Griffith JQ. The rat in laboratory investigation. 2ed. New York: Hafner; 1963. p. 24-50.

16.Llaneza PP, Salt WB. Vôlvulo gástrico: qual o tratamento apropriado? In: Barkin JS, Rogers AI. Decisões em gastrenterologia. Rio de Janeiro: Qualytimark; 1991.p. 75-100.

17.Lewis S, Holbrook A, Hersch P. An unusual case of massive gastric distension with catastrophic sequelae. Acta Anaesthesiol Scand. 2005;49(1):95-7.

18.Matthiensen DT. Fisiopatologia da dilatação gástrica: vólvulo. In: Bojrab MJ. Mecanismo da moléstia na cirurgia de pequenos animais. 2 ed. São Paulo: Manole; 1996. p. 260-73.

Conflict of interest: none

Financial source: none

\section{Correspondence:}

José Roberto F. Santiago

Av. Mario Ranieri, 4-45 H7

17015-430 Bauru - SP Brazil

Phone: (55 14)3236-2469

jrfsantiago@uol.com.br

Received: March 24, 2008

Review: May 27, 2008

Accepted: June 25, 2008

\section{How to cite this article}

Santiago JRF, Kobayasi S. The effect of gastric dilatation in rats submitted to gasified water ingestion under the hepatic metabolic function. Acta Cir Bras. [serial on the Internet] 2008 Sept-Oct;23(5). Available from URL: http://www.scielo.br/acb 